\title{
THE RENAL RESPONSE IN MAN TO ACUTE EXPERIMENTAL RESPIRATORY ALKALOSIS AND ACIDOSIS 1
}

\author{
BY E. S. BARKER, ${ }^{2,} 8$ R. B. SINGER,4 J. R. ELKINTON,2 AND J. K. CLARK \\ (From the Renal Section and Chemical Section of the Department of Medicine, The Department \\ of Research Medicine, and the Department of Biochemistry, the University of \\ Pennsylvaria School of Medicine, Philadelphia, Pa.)
}

(Submitted for publication August 7, 1956; accepted December 6, 1956)

The experimental results to be presented here deal with the renal component of the multiple effects in man of acute experimental respiratory alkalosis (hyperventilation) and acidosis $\left(\mathrm{CO}_{2}\right.$ inhalation). One aim of the experiments has been to define an integrated picture of the total body response to acute respiratory acid-base disturbances. A previous paper (1) contained a description of the effects observed in the same experiments on the composition of plasma and red cells, and a quantitative estimate of the exchanges of ions and water between red cells, plasma, extracellular fluids and a phase or phases outside the chloride space ("intracellular"). In the present report consideration is given to the changes in renal excretion and hemodynamics and an attempt is made to define more clearly certain mechanisms involved. Reference should be made to the previous report (1) for data on the blood or plasma changes; only a few of these data are included here when they are directly important to interpretation and renal effects. The present findings were previously reported in abstract $(2,3)$.

\section{EXPERIMENTAL PROCEDURE AND CHEMICAL} METHODS

Six normal male subjects actively hyperventilated and six inhaled $\mathrm{CO}_{2}$ as described in detail in the preceding paper (1). Following control periods of 47 to $74 \mathrm{~min}$ utes' duration, hyperventilation was carried out for ap-

1 Laboratory facilities were aided by grants from the National Heart Institute of the United States Public Health Service (Grants H-405 and H-340), the Life Insurance Medical Research Fund, and the C. Mahlon Kline Fund for Development in the Department of Medicine.

2 Established Investigator of the American Heart Association.

${ }^{8}$ In part during tenure of Post-doctorate Fellowship of the National Institutes of Health, United States Public Health Service.

4 Present address: 501 Boylston Street, Boston, Mass. proximately 30 minutes in 5 of the 6 experiments, and for twice that period in the last experiment; 7.5 to 7.7 per cent $\mathrm{CO}_{2}$ in air or oxygen was inhaled for 21 to 30 minutes. Measurements were continued in both types of experiments during subsequent recovery periods which ended 97 to 145 minutes after onset of the stimulus (designated time zero). Standard water loading was carried out before the experiments and continued throughout with water given in amounts equivalent to urine excreted. In respiratory acidosis a neutral or slightly alkaline control urine was considered desirable to facilitate observation of renal effects. Accordingly, in experiments 1 to 5 inclusive, the subjects were given $4.2 \mathrm{gm}$. $\mathrm{NaHCO}_{8}$ ( $50 \mathrm{mEq}$.) by mouth at -95 to -150 minutes. As a control, in the sixth experiment $\mathrm{NaCl}$ was substituted for the $\mathrm{NaHCO}_{8}$ and this experiment is not included in statistical analyses. Four additional control experiments were done in which the $\mathrm{NaHCO}_{2}$ load was given, and observations were made for the usual experimental time (but with no respiratory stimulus) to indicate the effect of the loading procedure alone.

Renal clearances were determined by standard techniques and chemical methods $(4,5)$, with bladder catheterization and appropriate anaerobic collection of urine to prevent loss of $\mathrm{CO}_{2}$. Changes in glomerular filtration rate were estimated from changes in endogenous creatinine clearance and effective renal plasma flow from p-aminohippurate (PAH) clearance. ${ }^{5}$ Following an equilibration period of at least 45 minutes urine was collected for 3 periods before, 1 to 4 periods during, and 3 to 4 periods after the application of the stimulus (hyperventilation or $\mathrm{CO}_{2}$ inhalation).

Total $\mathrm{CO}_{2}$ was determined in the anaerobically collected urine by the manometric method of Van Slyke and Sendroy (6), urine $\mathrm{pH}$ at $37^{\circ} \mathrm{C}$ by means of the photocolorimetric method of Van Slyke, Weisiger, and Van Slyke (7), sodium and potassium with a Barclay internal standard flame photometer (8), chloride by the

5 Excretion of anionic $\mathrm{PAH}^{-}$in itself has some effect on urinary acid-base pattern. Administration was, however, at the same slow rate during both control and experimental periods and there were no significant changes in PAH excretion during either type of respiratory stimulus, when urinary acid-base changes were maximal. PAH could also form a buffer pair, but because it would be a strong acid buffer $\left(\mathrm{pK}^{\prime}=3.83\right)(13)$, such an effect must be very small. 
Volhard-Harvey method (9), ammonia by the method of Folin and Bell (10) using a Klett-Summerson photometer, phosphate by the method of Lowry and Lopez (11), and titratable acidity by titrating to $\mathrm{pH}$ 7.4. The bicarbonate concentration was calculated from the total $\mathrm{CO}_{2}$ content and $\mathrm{pH}$ of each urine specimen by use of factors for $\mathrm{CO}_{2}$ solubility and $\mathrm{pK}^{\prime}$ in urine as functions of urinary total cation concentration, derived from Sendroy, Seelig, and Van Slyke (12).

Methods of blood sampling and analyses were described in the previous paper (1).

\section{Calculations}

Urinary electrolytes in microequivalents per minute ( $\mu$ Eq. per min.) are presented as excretion rates (UV) rather than clearances, thus permitting immediate comparison of cation-anion equivalents. The cations determined were sodium, potassium, and ammonium; the anions were chloride, bicarbonate, and (in part) phosphate.

Magnitude of acid-base disturbances $\left(\mathrm{SHCO}_{\mathrm{ser}}^{-}\right)$. Under conditions termed a "steady state" the rate at which carbon dioxide from cellular metabolism is added to the extracellular fluid equals the rate at which it is lost from the body, and there is no resulting acid-base effect on the extracellular fluid. When the pulmonary component is disturbed, as by hyperventilation or $\mathrm{CO}_{2}$ inhalation, a net quantity of $\mathrm{CO}_{2}$ is removed from or added to the extracellular fluid. An acid-base effect is exerted by shifting the following relationship toward either the left or right:

$$
\mathrm{CO}_{2}+\mathrm{H}_{2} \mathrm{O} \rightleftharpoons \mathrm{H}_{2} \mathrm{CO}_{3} \rightleftharpoons \mathrm{H}^{+}+\mathrm{HCO}_{3}^{-}
$$

This disturbance may be expressed in terms of equivalents as a change in $\mathrm{HCO}_{3}^{-}$, and this change is proposed for the purposes of this paper as an indication of the magnitude of the acid-base disturbance. $\triangle \mathrm{HCO}_{8}^{-}$is defined as the change in total amount of bicarbonate in the extracellular fluid (plasma plus interstitial fluid) and in the red cells. It is desirable to include the red cells since they are intimately related by the chloride shift to the acidbase changes of respiratory disturbances. The method of determination, together with observed $\triangle \mathrm{HCO}_{\mathrm{s}}^{-}$in the individual experiments, was given for a different purpose in the portion of the work previously published (1).

From Equation 1 it is evident that a change in $\mathrm{H}^{+}$ equivalent to that in $\mathrm{HCO}_{3}^{-}$must initially occur. However, at $\mathrm{pH}$ ranges compatible with life, free hydrogen ion concentration is always insignificant compared to the other ions. Accordingly, "buffering" mechanisms must accept the hydrogen ion in one type of disturbances or furnish it in the other. ${ }^{6}$

- The role of such mechanisms was estimated quantitatively, and it was noted that participation of some phase of body fluid outside the blood and typical interstitial fluid appears in these particular experiments to account for about two-thirds of the buffering of the hydrogen ion disturbance that would otherwise be present in the extracellular fluid (1).
Changes in rate of urinary hydrogen ion excretion $\left(\Delta U V_{H^{+}}\right)$. For the purpose of this paper a quantitative index of rate of $\mathrm{H}^{+}$excretion is defined as the sum of three components : $\mathrm{NH}_{4}^{+}$output plus titratable acid minus the $\mathrm{HCO}_{8}^{-}$output. In the case of an alkaline urine the rate is a negative quantity dependent chiefly on the bicarbonate output while for urine of neutral or slightly acid $\mathrm{pH}$ values, all three terms are significant fractions of the total. Excretion of bicarbonate is equivalent in acid-base effect to the addition of hydrogen ion to the body and this method of calculating $\mathrm{UV}_{\mathbf{H}^{+}}$eliminates the necessity of treating $\mathrm{HCO}_{8}^{-}$output as a separate factor. It is frequently not possible to distinguish, in the case of two separate body fluids, transfer of $\mathrm{H}^{+}$in one direction from transfer of $\mathrm{HCO}_{8}^{-}$in the opposite direction.

In order to assess the rate of renal acid-base compensation to the respiratory disturbance it is desirable to consider the difference between $\mathrm{UV}_{\mathbf{H}^{+}}$observed and the $\mathrm{UV}_{\mathbf{H}^{+}}$which would have been present at the control rate. The change in urinary hydrogen ion excretion is therefore determined, thus,

$$
\Delta \mathrm{UV}_{\mathrm{H}^{+}}=\Delta \mathrm{UV}_{\mathrm{NH}_{4^{+}}}+\Delta \mathrm{UV}_{\mathrm{T \Lambda}}-\Delta \mathrm{UV}_{\mathrm{HCO}_{8}}
$$

This consideration of $\Delta U V_{\mathbf{H}^{+}}$rather than $U V_{\mathbf{H}^{+}}$in absolute terms also avoids arbitrary decisions on what constitutes a "neutral" urine as related to an extracellular fluid $\mathrm{pH}$ about 7.4 and a usual dietary intake and metabolism which, uncompensated, would produce a metabolic acidosis.

It should be noted that under these experimental conditions, once hyperventilation or $\mathrm{CO}_{2}$ inhalation ceases the acid-base disturbance is rapidly corrected by respiratory adjustments. Therefore the most meaningful indications of urinary adjustments appear to be the peak $\Delta U V_{\mathbf{H}^{+}}$ achieved and the cumulative change to the time the respiratory stimulus was discontinued.

\section{RESULTS}

The results are presented in Tables I A, I B, II and III and in Figures 1 through 4 and were evaluated by standard statistical methods. The average control data are included in the figures and the average changes, variability (standard error) and probability of chance occurrence are shown below the graphic part of each figure. Changes in urinary excretion rates during respiratory alkalosis or acidosis as mentioned hereafter are the mean change (from control rates) observed in the last urine collection period during hyperventilation or $\mathrm{CO}_{2}$ inhalation.

\section{Respiratory alkalosis}

The magnitude of the acid-base disturbance was indicated by an average $\Delta \mathrm{HCO}^{-}{ }_{\mathrm{er}}$ of $-135 \mathrm{mEq}$. observed at the end of the period of hyperventila- 


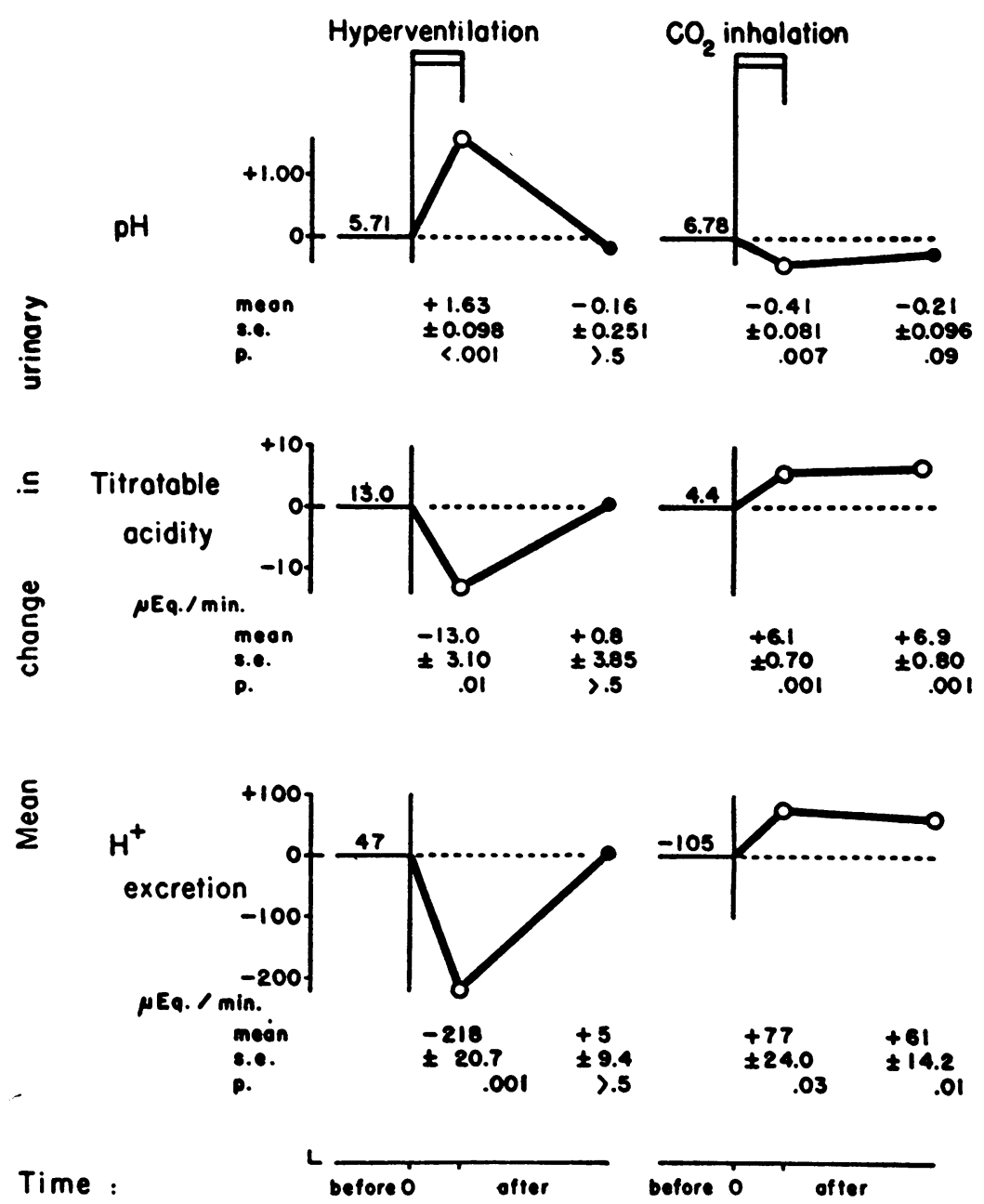

Fig. 1. Acute Respiratory Alkalosis and Acidosis: Mean Changes in Urinary PH aNd THe Excretion of Titratable ACID aNd Hydrogen IoN

The mean for each group of changes from the individual mean control values is plotted for the end of the period of stimulus and the end of the experiment. The values for the mean change, its standard error, and the probability of chance occurrence are given below the curves. The mean changes that are statistically significant ( $p=0.05$ or less) are represented by open circles. The abscissae represent time before, during, and after the stimulus. The mean of the control values is given on the horizontal axis. Hydrogen ion excretion is defined as the sum of outputs of ammonium plus titratable acidity minus bicarbonate (see Equation 2 in text).

tion. The rate of renal adjustment to the disturbance by retaining $\mathrm{H}^{+}$ion as compared to control $\mathrm{H}^{+}$output ( $\triangle \mathrm{UV}_{\mathbf{H}^{+}}$by Equation 2 ) averaged 218 $\mu$ Eq. per minute for the final period during hyperventilation. During the 30 minutes of the stimulus an average of $5.9 \mathrm{mEq}$. $\mathrm{H}^{+}$had been retained in this way. During hyperventilation the $\mathrm{pH}$ of the urine rose (mean $=+1.63 \mathrm{pH}$ units) and titratable acidity fell ( $-13.0 \mu \mathrm{Eq}$. per min.), both returning to the control values during the recovery period after hyperventilation. Bicarbonate excretion was markedly increased ( $+183 \mu \mathrm{Eq}$. per min.) and ammonium ion excretion decreased ( $-30 \mu$ Eq. per min.); each subsequently re- 


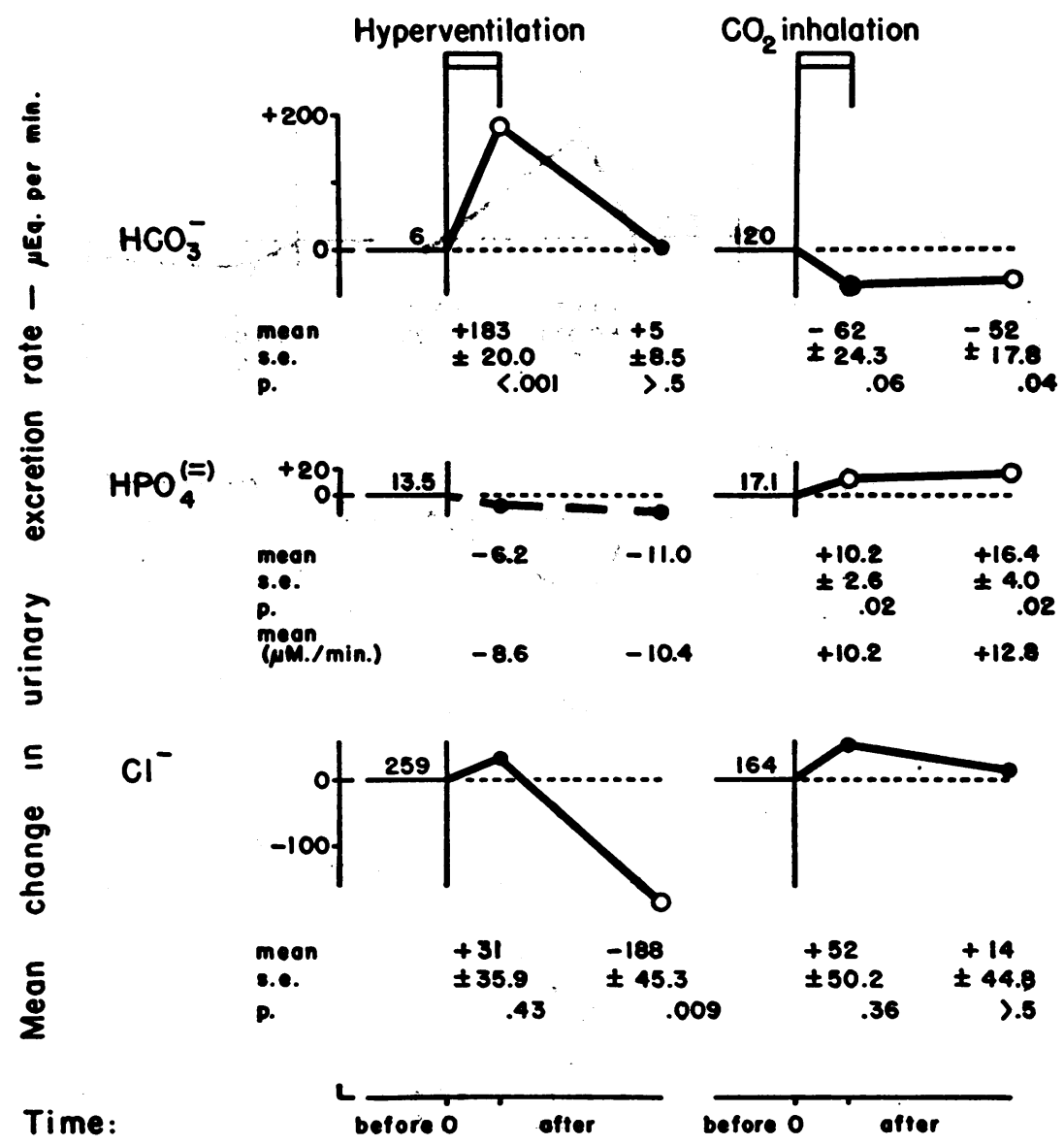

Fig, 2. Acute Respiratory Alzalosis and Acidosis: Mran Changes in THE URINARY Excretion RATES OF ANIONS

The data are presented as in Figure 1. Since phosphate was measured in only two of the hyperventilation experiments, it is shown with a dotted line and statistical analysis omitted. The symbol $\mathrm{HPO}_{4}{ }^{(\Leftrightarrow)}$ indicates phosphate both as $\mathrm{HPO}_{4}=$ and $\mathrm{H}_{2} \mathrm{PO}_{4}^{-}$.

turned to control rates. Potassium excretion increased markedly ( $+183 \mu$ Eq. per min.), while neither sodium nor chloride excretion showed a statistically significant change. In the recovery period excretion rates fell significantly below control for each of these ions (mean changes in rate per min.: $\mathrm{K}^{+}-71 \mu \mathrm{Eq} ., \mathrm{Na}^{+}-155 \mu \mathrm{Eq} ., \mathrm{Cl}^{-}$ $-188 \mu$ Eq.).

\section{Respiratory acidosis}

It is clearly shown by comparison of the magnitude of the estimated acid-base disturbance $\left(\triangle \mathrm{HCO}_{\mathrm{er}}^{-}=26 \mathrm{mEq}\right.$.), or of plasma acid-base data (1), that $\mathrm{CO}_{2}$ inhalation was a milder acidbase disturbance than hyperventilation. It is dif- ficult to achieve a more severe acute experimental respiratory acidosis without undesirable side effects. Changes in urinary findings were correspondingly smaller during $\mathrm{CO}_{2}$ inhalation than those observed during hyperventilation. $\Delta \mathrm{UV}_{\mathbf{H}^{+}}$ averaged $77 \mu$ Eq. per minute and cumulative $\mathrm{H}^{+}$ eliminated during the stimulus was $1.9 \mathrm{mEq}$. Urinary $\mathrm{pH}$ fell $(-0.41 \mathrm{pH}$ units $)$ and titratable acidity increased ( $+6.1 \mu \mathrm{Eq}$. per min.). Bicarbonate excretion decreased $(-62 \mu \mathrm{Eq}$. per min.) in spite of a considerable increase in filtered load that resulted from the increased plasma concentration during $\mathrm{CO}_{2}$ inhalation. The change in bicarbonate reabsorption ( $+310 \mu \mathrm{Eq}$. per min.) is accordingly significant $(p=0.03)$. Thus a 


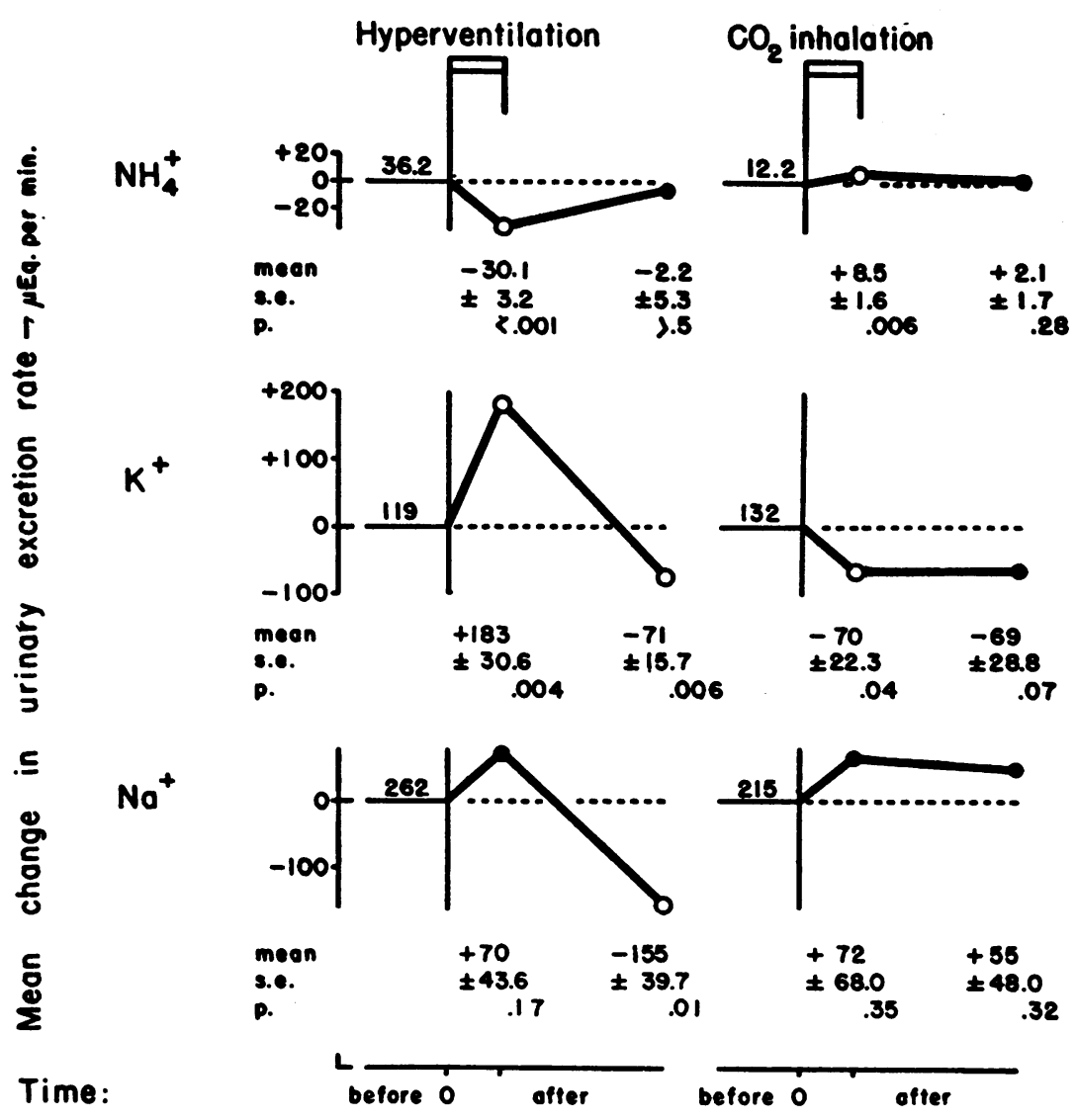

Fig. 3. Acute Respiratory Alralosis and Acidosis: Mean Changes in the Urinary Excretion Rates of Cations

The data are presented as in Figure 1.

real physiologic response in bicarbonate regulation is evident, although if changes in excretion alone are considered the results just fail $(p=$ $0.06)$ to show "statistical significance." Excretion of ammonium ion increased $(+8.5 \mu \mathrm{Eq}$. per min.) and that of potassium decreased $(-70 \mu \mathrm{Eq}$. per min.). Neither sodium nor chloride output showed statistically significant change. Phosphate excretion was increased ( $+10 \mu \mathrm{Eq}$. per min.).

The small oral dose of sodium bicarbonate given preceding the respiratory acidosis experiments established a "baseline" (a neutral or alkaline urine) upon which the effect of the $\mathrm{CO}_{2}$ inhalation could be more readily determined. Effects of the bicarbonate dose are evident in differences between the average control values in the respiratory alkalosis and acidosis experiments as shown in Figures 1 to 4 . Four additional experiments

\begin{tabular}{|c|c|c|c|c|}
\hline & $\begin{array}{c}\text { PLASMA } \\
\text { pH }\end{array}$ & $\begin{array}{c}\text { URINARY } \\
\text { HCO,- } \\
\text { EXCRETION }\end{array}$ & $\begin{array}{c}\text { TUBULAR } \\
\text { HCO5: } \\
\text { REAasoneTION }\end{array}$ & $\begin{array}{l}\text { PLASMA } \\
. \mathrm{CO}_{2}\end{array}$ \\
\hline $\begin{array}{l}\text { RESPIRATORY } \\
\text { ACIDOSIS }\end{array}$ & & & & \\
\hline $\begin{array}{l}\text { RESPIRATORY } \\
\text { ALKALOSIS }\end{array}$ & & & & \\
\hline $\begin{array}{l}\text { METABOLIC } \\
\text { HCO, ADMBNS } \\
\text { ALKALOSIS }\end{array}$ & & & & \\
\hline
\end{tabular}

Fig. 4. Changes in NaHCO, Excretion, Reabsorption aNd Remated Extracellular Flum (Plasma) Factors in Acute Respiratory Alralosis and AcmoSIS AND IN Metabolic Alralosis

Direction of change in response to the stimulus is indicated by the arrows. For each type of disturbance the plasma $\mathrm{HCO}_{8}^{-}$concentration changed in the same direction as the $\mathrm{PCO}_{2}$. The rate of filtration of $\mathrm{HCO}_{3}^{-}$(or $\mathrm{HCO}_{8}^{-}$load) also changed in this direction. 
E. S. BARKER, R. B. SINGER, J. R. ELKINTON, AND J. K. CLARK

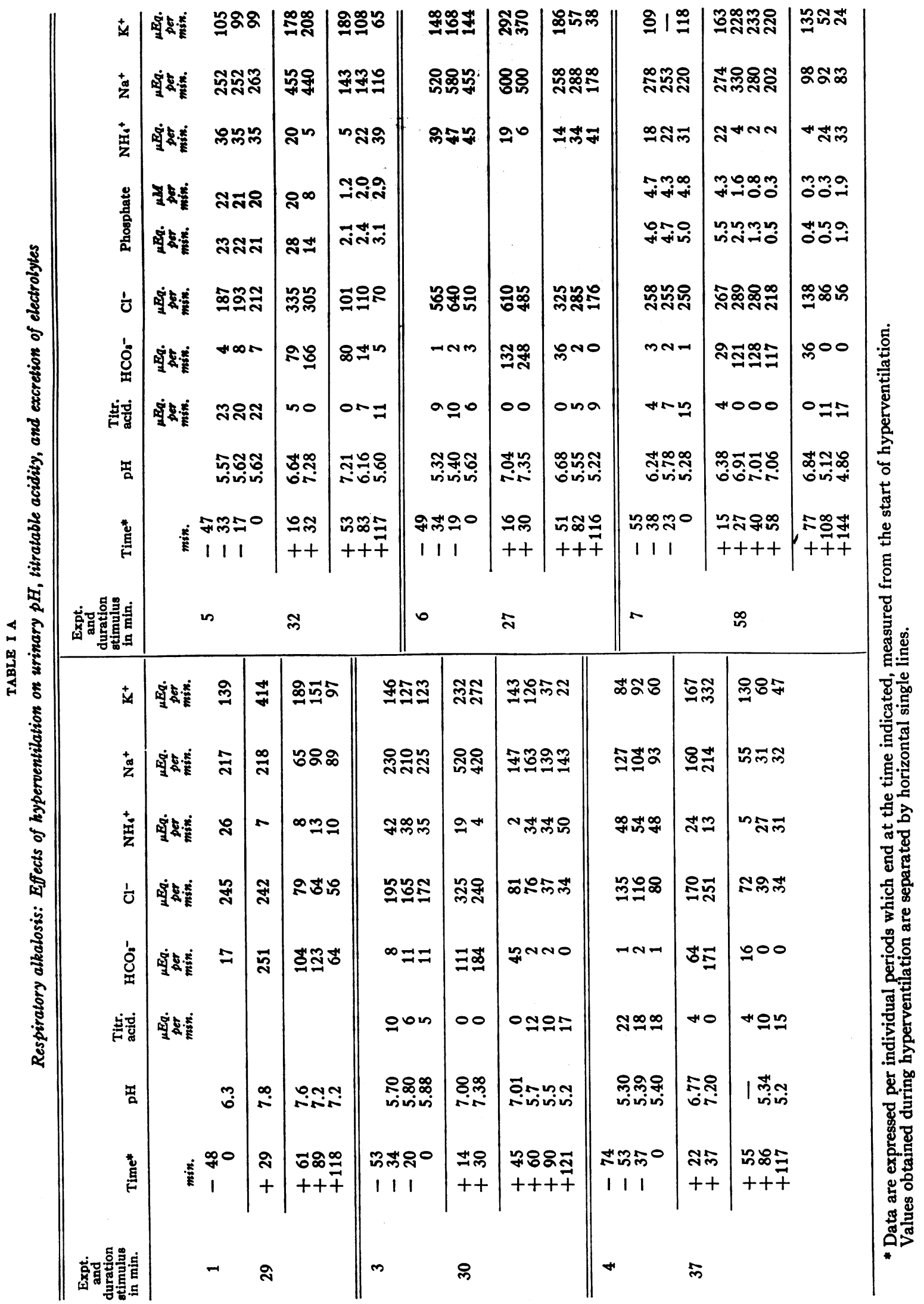


RENAL RESPONSE TO RESPIRATORY ALKALOSIS AND ACIDOSIS

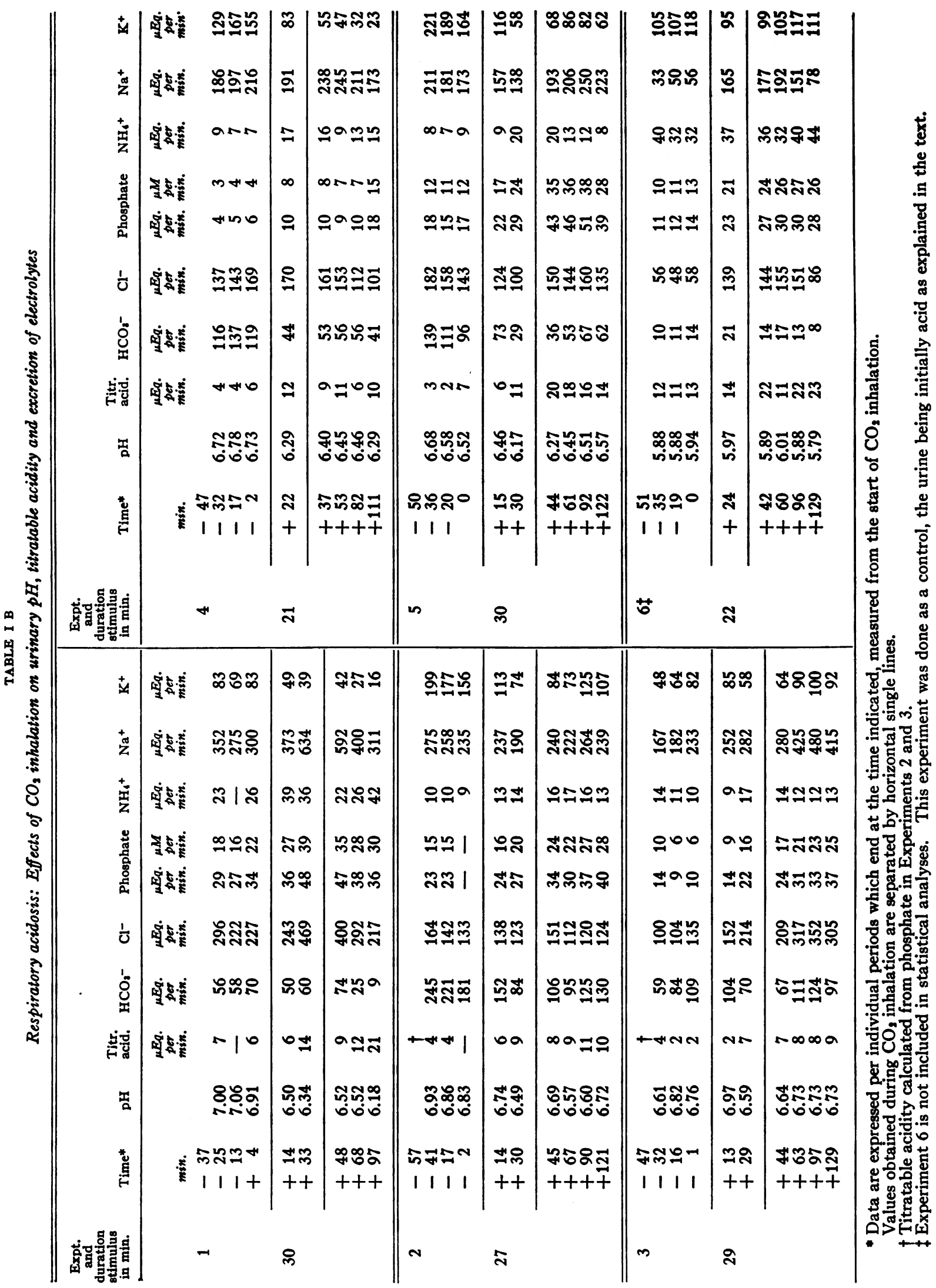


TABLE II

Respiratory alkalosis and acidosis: Calculated extracellular acid-base disturbance $\left(\triangle \mathrm{HCO}_{3}^{-}\right)^{*}$ and renal compensation $\left(\Delta U V_{B^{+}}\right) \dagger$ at end of respiratory stimulus

\begin{tabular}{|c|c|c|c|c|c|c|c|}
\hline \multicolumn{4}{|c|}{$\begin{array}{l}\text { A. Respiratory alkalosis } \\
\text { (hyperventilation) }\end{array}$} & \multicolumn{4}{|c|}{$\begin{array}{l}\text { B. Respiratory acidosis } \\
\text { (CO\& inhalation) }\end{array}$} \\
\hline \multirow[b]{2}{*}{ Expt. } & \multirow[b]{2}{*}{$\triangle \mathrm{HCO}_{3}^{-}$} & \multicolumn{2}{|c|}{$\Delta U_{\mathbf{H}^{+}}$} & \multirow[b]{2}{*}{ Expt. } & \multirow[b]{2}{*}{$\triangle \mathrm{HCO}_{3}^{-}$or } & \multicolumn{2}{|c|}{$\Delta \mathrm{UV}_{\mathrm{H}^{+}}$} \\
\hline & & Rate & Cumulative & & & Rate & Cumulative \\
\hline & $m E q$. & $\begin{array}{l}\mu E q_{.} \text {per } \\
\text { min. }\end{array}$ & $m E q$ & & $m E q$. & $\begin{array}{l}\mu E q_{\text {. per }} \\
\text { min. }\end{array}$ & $m E q$. \\
\hline $\begin{array}{l}3 \\
4 \\
5 \\
6 \\
7\end{array}$ & $\begin{array}{r}-141 \\
-189 \\
-125 \\
-152 \\
-67\end{array}$ & $\begin{array}{l}-215 \\
-226 \\
-212 \\
-292 \\
-146\end{array}$ & $\begin{array}{l}-5.0 \\
-5.6 \\
-5.0 \\
-6.7 \\
-7.0\end{array}$ & $\begin{array}{l}1 \\
2 \\
3 \\
4 \\
5\end{array}$ & $\begin{array}{l}+46 \\
+12 \\
+38 \\
+2 \\
+31\end{array}$ & $\begin{array}{r}+20 \\
+142 \\
+23 \\
+97 \\
+105\end{array}$ & $\begin{array}{l}+0.64 \\
+4.3 \\
+0.16 \\
+2.3 \\
+2.2\end{array}$ \\
\hline Mean & -135 & -218 & -5.9 & Mean & +26 & +77 & +1.9 \\
\hline
\end{tabular}

* $\Delta \mathrm{HCO}_{3}$ - indicates the total change in bicarbonate of the extracellular fluid (plasma plus interstitial fluid) and of the red cells (1).

$+\Delta \mathrm{UV}_{\mathrm{H}^{+}}$indicates the change from control in urinary hydrogen ion excretion defined as the sum of ammonium plus titratable acid minus bicarbonate output (see Equation 2 in text).

were done without any disturbance of respiration to evaluate the effect of the oral bicarbonate alone. These experiments also provided a control for the acidosis series with respect to the effects of the diurnal "tide" and the water loading procedure. While slight apparent changes were present at the times that would correspond to the respiratory stimulus, none of them was statistically significant. Changes during the stimulus in the respiratory acidosis series which are significantly different from the preceding control values also differ significantly from the slight alterations at corresponding times in the control series. This is true for all of the variables except urinary $\mathrm{pH}$ and $\mathrm{K}^{+}$excretion, the differences of which were not quite significant at the 5 per cent level. During the comparatively longer recovery portion of the experiments, a tendency in the acidosis series to disappearance of the effects of the oral bicarbonate on the "baseline" would be indistinguishable from persistence of acidification of the urine as a compensatory mechanism to the respiratory disturbance. Accordingly, discussion of changes late in recovery is limited to respiratory alkalosis. Results are not reported in detail for the control series.

\section{Renal hemodynamics and urinary volume}

Measurements made of effective renal plasma flow, glomerular filtration rate, and rates of urine flow are not reported in detail. Significant changes were observed only with hyperventilation. Ef- fective renal plasma flow was depressed from control at the end of these experiments, a change correlating with the excretion rate of sodium and chloride which were also significantly depressed at this time. Glomerular filtration rate was also decreased significantly at the end of the experiments, but also decreased somewhat during the hyperventilation, at a time when excretion of sodium and chloride and effective plasma flow were not significantly altered and if anything were a little increased. Changes in urine flow were probably more closely related to the water loading than to the experimental procedure.

\section{DISCUSSION}

\section{Observation of renal acid-base adjustment}

The kidney responds promptly to primary respiratory alterations of acid-base equilibrium. The renal adjustment is not a simple correction of the abnormality present, but may be considered as eventually producing an opposing "metabolic" (as contrasted to "respiratory") disturbance which may be measured as a change in the rate of hydrogen ion excretion $\left(\Delta U V_{\mathbf{H}^{+}}\right)$. An increase in $U V_{\mathbf{H}^{+}}$is equivalent to an increase in buffer base in the body. Singer and Hastings (14) suggested certain practical advantages in focussing attention on the buffer base concentration as a quantitative index of the metabolic or non-respiratory factor in acid-base equilibrium and pointed out that a pure respiratory disturbance (before various com- 
TABLE III

Respiratory alkalosis and acidosis: Renal filtration, reabsorption and excretion of bicarbonate

\begin{tabular}{|c|c|c|c|c|c|c|c|c|c|c|}
\hline \multirow[b]{4}{*}{ Expt. } & \multirow[b]{4}{*}{ Time* } & \multirow{3}{*}{$\begin{array}{l}\text { Urine } \\
\text { flow }\end{array}$} & \multirow{4}{*}{$\frac{\text { GFR }}{\text { in. }}$} & \multirow{2}{*}{\multicolumn{3}{|c|}{ Plasma }} & \multicolumn{4}{|c|}{$\mathrm{HCO}_{2}^{-}$} \\
\hline & & & & & & & \multirow{3}{*}{$\underset{\substack{\text { Filt. } \\
\text { per } \\
\text { min. }}}{\text {. }}$} & \multirow{3}{*}{$\begin{array}{c}\text { Excr. } \\
\text { mEq. } \\
\text { per. } \\
\text { min. }\end{array}$} & \multicolumn{2}{|c|}{ Reabeorbed } \\
\hline & & & & \multirow[t]{2}{*}{$\mathrm{pH}$} & \multirow{2}{*}{$\begin{array}{c}\mathrm{PCO}_{2} \\
m m . \mathrm{Hg}_{\mathrm{g}}\end{array}$} & \multirow{2}{*}{ 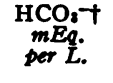 } & & & \multirow{2}{*}{$\begin{array}{c}m R_{q} . \\
\text { per } \\
\text { min. }\end{array}$} & \multirow{2}{*}{$\begin{array}{l}m E q . \\
\text { per } L . \\
\text { filtrate }\end{array}$} \\
\hline & & ml. & & & & & & & & \\
\hline \multicolumn{11}{|c|}{ A. Respiratory alkalosis-hyperventilation } \\
\hline 3 & $\begin{array}{l}C^{*} \\
\mathbf{S} \\
\mathbf{R}\end{array}$ & $\begin{array}{r}10.4 \\
5.0 \\
1.9\end{array}$ & $\begin{array}{l}125 \\
109 \\
124\end{array}$ & $\begin{array}{l}7.38 \\
7.62 \\
7.40\end{array}$ & $\begin{array}{l}43 \\
19 \\
42\end{array}$ & $\begin{array}{l}24.9 \\
19.2 \\
25.4\end{array}$ & $\begin{array}{l}3.11 \\
2.09 \\
3.15\end{array}$ & $\begin{array}{r}.010 \\
.184 \\
0\end{array}$ & $\begin{array}{l}3.10 \\
1.91 \\
3.15\end{array}$ & $\begin{array}{l}24.82 \\
17.52 \\
25.42\end{array}$ \\
\hline 4 & $\begin{array}{l}\mathbf{C} \\
\mathbf{S} \\
\mathbf{R}\end{array}$ & $\begin{array}{l}6.6 \\
6.2 \\
0.5\end{array}$ & $\begin{array}{r}104 \\
108 \\
80\end{array}$ & $\begin{array}{l}7.35 \\
7.65 \\
7.43\end{array}$ & $\begin{array}{l}43 \\
15 \\
37\end{array}$ & $\begin{array}{l}23.6 \\
16.5 \\
24.4\end{array}$ & $\begin{array}{l}2.45 \\
1.78 \\
1.95\end{array}$ & $\begin{array}{r}.001 \\
.171 \\
0\end{array}$ & $\begin{array}{l}2.45 \\
1.61 \\
1.95\end{array}$ & $\begin{array}{l}23.58 \\
14.92 \\
24.41\end{array}$ \\
\hline 5 & $\begin{array}{l}\text { C } \\
\text { S } \\
\text { R }\end{array}$ & $\begin{array}{r}12.1 \\
5.3 \\
9.3\end{array}$ & $\begin{array}{r}122 \\
87 \\
118\end{array}$ & $\begin{array}{l}7.39 \\
7.63 \\
7.44\end{array}$ & $\begin{array}{l}43 \\
19 \\
39\end{array}$ & $\begin{array}{l}25.6 \\
20.2 \\
25.7\end{array}$ & $\begin{array}{l}3.13 \\
1.76 \\
3.03\end{array}$ & $\begin{array}{l}.006 \\
.166 \\
.005\end{array}$ & $\begin{array}{l}3.12 \\
1.59 \\
3.03\end{array}$ & $\begin{array}{l}25.58 \\
18.29 \\
25.67\end{array}$ \\
\hline 6 & $\begin{array}{l}\mathrm{C} \\
\mathrm{S} \\
\mathrm{R}\end{array}$ & $\begin{array}{l}7.5 \\
7.8 \\
3.8\end{array}$ & $\begin{array}{r}109 \\
86 \\
96\end{array}$ & $\begin{array}{l}7.39 \\
7.66 \\
7.43\end{array}$ & $\begin{array}{l}43 \\
16 \\
37\end{array}$ & $\begin{array}{l}25.3 \\
17.9 \\
24.2\end{array}$ & $\begin{array}{l}2.76 \\
1.54 \\
2.32\end{array}$ & $\begin{array}{r}.002 \\
.248 \\
0\end{array}$ & $\begin{array}{l}2.76 \\
1.29 \\
2.32\end{array}$ & $\begin{array}{l}25.28 \\
15.00 \\
24.20\end{array}$ \\
\hline 7 & $\begin{array}{l}\mathbf{C} \\
\mathbf{S} \\
\mathbf{R}\end{array}$ & $\begin{array}{l}1.6 \\
5.9 \\
3.9\end{array}$ & $\begin{array}{l}132 \\
108 \\
109\end{array}$ & $\begin{array}{l}7.30 \\
7.56 \\
7.39\end{array}$ & $\begin{array}{l}44 \\
25 \\
42\end{array}$ & $\begin{array}{l}24.9 \\
22.2 \\
24.9\end{array}$ & $\begin{array}{l}3.29 \\
2.40 \\
2.71\end{array}$ & $\begin{array}{r}.002 \\
.117 \\
0\end{array}$ & $\begin{array}{l}3.29 \\
2.28 \\
2.71\end{array}$ & $\begin{array}{l}24.89 \\
21.13 \\
24.89\end{array}$ \\
\hline \multicolumn{11}{|c|}{ B. Respiratory acidosis- $-\mathrm{CO}_{2}$ inhalation } \\
\hline 1 & $\begin{array}{l}\mathbf{C} \\
\mathbf{S} \\
\mathbf{R}\end{array}$ & $\begin{array}{r}3.0 \\
17.2 \\
4.0\end{array}$ & $\begin{array}{l}139 \\
151 \\
135\end{array}$ & $\begin{array}{l}7.40 \\
7.35 \\
7.45\end{array}$ & $\begin{array}{l}46 \\
54 \\
40\end{array}$ & $\begin{array}{l}27.5 \\
29.9 \\
27.0\end{array}$ & $\begin{array}{l}3.82 \\
4.52 \\
3.64\end{array}$ & $\begin{array}{l}.061 \\
.060 \\
.010\end{array}$ & $\begin{array}{l}3.76 \\
4.46 \\
3.64\end{array}$ & $\begin{array}{l}27.05 \\
29.53 \\
26.97\end{array}$ \\
\hline 2 & $\begin{array}{l}\text { C } \\
\text { S } \\
\text { R }\end{array}$ & $\begin{array}{l}18.2 \\
16.4 \\
17.2\end{array}$ & $\begin{array}{l}126 \\
127 \\
131\end{array}$ & $\begin{array}{l}7.46 \\
7.40 \\
7.43\end{array}$ & $\begin{array}{l}40 \\
47 \\
40\end{array}$ & $\begin{array}{l}27.8 \\
28.7 \\
26.5\end{array}$ & $\begin{array}{l}3.50 \\
3.64 \\
3.47\end{array}$ & $\begin{array}{l}.216 \\
.123 \\
.125\end{array}$ & $\begin{array}{l}3.29 \\
3.52 \\
3.35\end{array}$ & $\begin{array}{l}26.11 \\
27.71 \\
25.57\end{array}$ \\
\hline 3 & $\begin{array}{l}\mathbf{C} \\
\mathbf{S} \\
\mathbf{R}\end{array}$ & $\begin{array}{l}11.1 \\
10.6 \\
13.6\end{array}$ & $\begin{array}{l}111 \\
114 \\
117\end{array}$ & $\begin{array}{l}7.50 \\
7.37 \\
7.44\end{array}$ & $\begin{array}{l}34 \\
48 \\
37\end{array}$ & $\begin{array}{l}25.5 \\
27.1 \\
24.4\end{array}$ & $\begin{array}{l}2.83 \\
3.09 \\
2.86\end{array}$ & $\begin{array}{l}.084 \\
.070 \\
.111\end{array}$ & $\begin{array}{l}2.75 \\
3.02 \\
2.74\end{array}$ & $\begin{array}{l}24.76 \\
26.49 \\
23.42\end{array}$ \\
\hline 4 & $\begin{array}{l}\mathbf{C} \\
\mathbf{S} \\
\mathbf{R}\end{array}$ & $\begin{array}{l}16.7 \\
14.8 \\
15.8\end{array}$ & $\begin{array}{l}115 \\
117 \\
116\end{array}$ & $\begin{array}{l}7.44 \\
7.34 \\
7.48\end{array}$ & $\begin{array}{l}41 \\
51 \\
34\end{array}$ & $\begin{array}{l}26.7 \\
27.0 \\
24.6\end{array}$ & $\begin{array}{l}3.07 \\
3.16 \\
2.85\end{array}$ & $\begin{array}{l}.124 \\
.044 \\
.056\end{array}$ & $\begin{array}{l}2.95 \\
3.12 \\
2.80\end{array}$ & $\begin{array}{l}25.63 \\
26.68 \\
24.13\end{array}$ \\
\hline 5 & $\begin{array}{l}\mathbf{C} \\
\mathbf{S} \\
\mathbf{R}\end{array}$ & $\begin{array}{l}16.8 \\
13.1 \\
14.1\end{array}$ & $\begin{array}{l}108 \\
107 \\
106\end{array}$ & $\begin{array}{l}7.44 \\
7.33 \\
7.44\end{array}$ & $\begin{array}{l}38 \\
52 \\
26\end{array}$ & $\begin{array}{l}25.3 \\
26.5 \\
24.2\end{array}$ & $\begin{array}{l}2.73 \\
2.84 \\
2.57\end{array}$ & $\begin{array}{l}.115 \\
.029 \\
.053\end{array}$ & $\begin{array}{l}2.62 \\
2.81 \\
2.51\end{array}$ & $\begin{array}{l}24.26 \\
26.18 \\
23.68\end{array}$ \\
\hline $6 \ddagger$ & $\begin{array}{l}\mathbf{C} \\
\mathbf{S} \\
\mathbf{R}\end{array}$ & $\begin{array}{l}12.1 \\
15.3 \\
14.7\end{array}$ & $\begin{array}{l}102 \\
110 \\
106\end{array}$ & $\begin{array}{l}7.32 \\
7.26 \\
7.37\end{array}$ & $\begin{array}{l}49 \\
62 \\
45\end{array}$ & $\begin{array}{l}24.7 \\
27.1 \\
25.5\end{array}$ & $\begin{array}{l}2.52 \\
2.98 \\
2.70\end{array}$ & $\begin{array}{l}.012 \\
.021 \\
.013\end{array}$ & $\begin{array}{l}2.51 \\
2.96 \\
2.69\end{array}$ & $\begin{array}{l}24.60 \\
26.90 \\
25.38\end{array}$ \\
\hline
\end{tabular}

* Time of individual periods and respiratory stimuli is given in Table I A and I B.

$C$ denotes average of the control periods.

$S$ denotes the last period during the respiratory stimulus.

$R$ denotes the last period for which complete data were available during recovery from the effects of the stimulus. $\dagger$ The plasma concentration of $\mathrm{HCO}_{3}^{-}$given and used to calculate $\mathrm{HCO}_{3}-$ filtered is that observed (often at the end of the period) rather than an interpolated value for mid-period. No correction is made for serum water or Donnan factor.

$\ddagger$ Experiment 6 during $\mathrm{CO}_{2}$ inhalation was done as a control, the urine being initially acid as explained in the text.

pensations) causes no change in whole blood buf- monium excretion rather than by subtracting fer base. Fuller and MacLeod (15) have calcu- $\mathrm{HCO}_{\mathbf{3}}^{-}$excretion as we do in calculating $\mathrm{UV}_{\mathbf{H}^{+}}$. lated the rate of "total $\mathrm{H}^{+}$secretion" by adding The resulting index is quite different since our $\mathrm{HCO}_{\mathrm{s}}-$ reabsorption to titratable acidity plus am- index indicates the net effective acid-base adjust- 
ment accomplished by the over-all process of urine formation while theirs relates to the specific process of $\mathrm{H}^{+}$secretion by the tubular cells.

In respiratory alkalosis the characteristic response is a decrease in $\mathrm{H}^{+}$output, measured principally by an increase of $\mathrm{HCO}_{3}^{-}$with fixed cation in an alkaline urine (17-22). Associated with this is a decrease in output of ammonia and titratable acid. The resultant effect on total body fluids is a loss of buffer base, a further reduction of the already lowered $\mathrm{HCO}_{3}^{-}$concentration and a return of $\mathrm{pH}$ toward the normal range. The accompanying predominant change in excretion of "fixed" ion in the first half hour of acute experiments is increased $\mathrm{K}^{+}$loss, rather than change in $\mathrm{Na}^{+}$or $\mathrm{Cl}^{-}$. The duration of the experiments was such that cumulative excretion while the stimulus persisted had very little effect in changing extracellular or total body fluid buffer base. The renal compensation was therefore small compared to the rapid sharing of the effects of the stimulus by the various "buffer" mechanisms of the body previously estimated in detail (1). Calculations based on the data of other workers $(23,24)$ indicate that in more prolonged respiratory disturbances the major part of $\Delta \mathrm{HCO}_{\mathrm{er}}^{-}$may be compensated by cumulative urinary changes.

Renal compensation for acute respiratory alkalosis appears to be less efficient than that for acute metabolic alkalosis of the "electrolyte addition" type. In seven experiments in which we gave rapid intravenous infusions of hypertonic sodium bicarbonate $(25,26)$ the total dose of bicarbonate given was of the same order of magnitude as the $\Delta \mathrm{HCO}^{-}$er observed in respiratory alkalosis reported here. Yet, within the same time, cumulative $\Delta \mathrm{UV}_{\mathbf{H}^{+}}$averaged $19.6 \mathrm{mEq}$., indicating more than three times the comparable renal compensation during respiratory alkalosis. ${ }^{8}$ The difference

7 The use of the index proposed by these authors involves the assumption that the basic tubular process of $\mathrm{H}^{+}$secretion is involved in the entire quantity of $\mathrm{HCO}_{8}^{-}$ reabsorbed. This view is presently held by most workers, as they point out, but it has also been recently challenged (16).

8 For the bicarbonate administration studies renal adjustment was calculated by an alternative approximation rather than by $\Delta U V_{\mathbf{H}^{+}}$as defined in this paper. From the laws of buffer action and electroneutrality it follows that changes in $U V_{\mathbf{H}^{+}}$must be accompanied by an equal change in excretion of fixed cation minus fixed anion of may be related to the fact that this type of metabolic alkalosis (a simple excess of sodium and bicarbonate) may be corrected by the renal excretion of the ions present in excess.

The characteristic changes in respiratory acidosis are the opposite of those described for respiratory alkalosis $(15,17,27)$. There is an increase in excretion rates of $\mathrm{H}^{+}$, titratable acid and ammonia and a decrease in excretion of bicarbonate with fixed cation, especially potassium. The urine becomes more acid. Since the acid-base disturbance of acute experimental $\mathrm{CO}_{2}$ inhalation is considerably milder than that of hyperventilation, the urinary changes are much smaller in absolute terms. Relative to the estimated acid-base disturbance $\left(\Delta \mathrm{HCO}_{\mathrm{e}}^{-}\right)$, however, the renal response appears to be of the same order of magnitude. When the experiments were planned we postulated that it would be difficult to detect an increase in $\mathrm{UV}_{\mathbf{H}^{+}}$if the control urine were already acid. If the "basal" state of the kidney involves compensation for the tendency of the usual diet to produce a slight metabolic acidosis, it would scarcely be surprising that an acute respiratory acidosis of mild degree should fail to bring about a further detectable increase in $\mathrm{UV}_{\mathbf{H}^{+}}$. We believe that this is the explanation for the lack of response in urinary acid-base factors noted by Longson and Mills (28), and in urinary output of sodium, potassium and chloride by other workers (29), during acute $\mathrm{CO}_{2}$ inhalation in man. Similarly, in our Experiment 6, with $\mathrm{NaCl}$ substituted for the small pre-medication dose of $\mathrm{NaHCO}_{3}$ (and a control urine $\mathrm{pH}$ of 5.9) there was no detectable change in $\mathrm{UV}_{\mathbf{H}^{+}}$. In spite of the acid control urines, it seems probable that a renal tubular response could have been found in the experiments of Longson and Mills (28) had changes in filtered load and reabsorption of bi-

opposite algebraic sign. Under many circumstances, including our own experimental conditions, a fairly satisfactory approximation of $\Delta \mathrm{UV}_{\mathbf{H}^{+}}$can be derived from changes in excretion rates of the major fixed ions of urine, as $\mathrm{Na}^{+}+\mathrm{K}^{+}-\mathrm{Cl}^{-}$. Expression of the urinary adjustment in these alternative terms directs attention to the effect on body fluid content of the major fixed ions, which may be convenient in consideration of acid-base changes there. Use of this approximation during hyperventilation indicates an average change of $+222 \mu \mathrm{Eq}$. per min., surprisingly close to the $\Delta U V_{\mathbf{H}^{+}}$of $-218 \mu \mathrm{Eq}$. per min. by the other method. 
carbonate been determined rather than in excretion alone. Data of Denton, Maxwell, McDonald, Munro, and Williams (30) during $\mathrm{CO}_{2}$ inhalation in sheep indicate a marked rise in $\mathrm{HCO}_{8}^{-}$ reabsorption, although, like Longson and Mills, they observed no change in rate of urinary excretion of $\mathrm{HCO}_{3}^{-}$. In contrast to these negative urinary results other workers have found characteristic changes in urinary acid-base factors in acute respiratory acidosis in dogs $(15,17,31) .^{\circ}$ Where given, control urinary $\mathrm{pH}$ values in these experiments were close to 7.0 or above. We observed significant urinary changes in the five subjects who were given the preceding oral dose of $\mathrm{NaHCO}_{3}$, and in whom the control urine $\mathrm{pH}$ was also approximately neutral.

Other factors influence the characteristic renal response observed during respiratory acid-base disturbances. For example, the typical urinary response to respiratory alkalosis is lacking in subjects who are in a state of $\mathrm{NaCl}$ depletion (18, $20)$. It is to be expected that pre-existing disturbances of the circulation or fluid and electrolyte balance, endocrine factors, and kidney disease may alter the characteristic changes that have been defined.

In more prolonged respiratory disturbances (for example of four or five days' duration) the ability of the kidney to compensate appears increased over that seen initially (32). Ammonium excretion is likely to constitute a larger fraction of the renal response to more prolonged acidosis. Although $\mathrm{NH}_{4}^{+}$output begins to rise within a few minutes of onset of acidosis, it does not approach maximal rates for some hours or days (33).

\section{The urinary findings in different phases of re- spiratory acid-base disturbances}

It must be emphasized that the characteristic combination of urinary changes described above is typical only of the "displacement" phase of the respiratory disturbance. While changes in uri-

9 A change is evident in the urinary data of Fuller and MacLeod (15), although their calculation of "total $\mathrm{H}^{+}$ secretion" did not change significantly because of a fall in glomerular filtration rate and therefore in bicarbonate reabsorption. Their method of calculation showed that 90 to 98 per cent of "total $\mathrm{H}^{+}$secretion" was accounted for by bicarbonate reabsorption in respiratory disturbances. nary rates of $\mathrm{H}^{+}$excretion persist they result in a progressive increase in the degree of metabolic acidosis or alkalosis which compensates in part for the respiratory disturbance. If the abnormal level of $\mathrm{PCO}_{2}$ persists for periods much longer than the duration of the present experiments, eventually a point will be reached where the secondary change in extracellular buffer base and other chemical changes have restored the $\mathrm{pH}$ to a level of stability in or closer to the normal range. In the ensuing "steady state" phase of the disturbance renal compensation ceases, in the sense that no further progressive change is produced in buffer base of body fluids. Output of $\mathrm{H}^{+}$ then reflects the dietary intake and other physiological processes, as it does in a state of normal respiration and $\mathrm{PCO}_{2}$. Finally, during the "recovery" phase of a chronic respiratory acid-base disturbance, when $\mathrm{PCO}_{2}$ is returning toward normal, renal compensation serves to restore the extracellular buffer base to normal. Changes are therefore the precise opposite of those described for the displacement phase: increase in $\mathrm{UV}_{\mathbf{H}^{+}}$in chronic respiratory alkalosis, and decrease in chronic respiratory acidosis. Thus in chronic respiratory disturbances a temporary increase in the respiratory difficulty (equivalent to an additional "displacement" phase) will be accompanied by reappearance of characteristic urinary changes; a temporary decrease in the respiratory difficulty (equivalent to a partial "recovery" phase) will cause the opposite type of urinary changes. Such a sequence of events is quite otherwise to the situation found in metabolic acid-base disturbances. In a complete study of the displacement, stabilization, and recovery phases of ammonium chloride acidosis, Sartorius, Roemmelt, and Pitts (33) have shown that the fundamental urinary response is one of increased $\mathrm{UV}_{\mathbf{H}^{+}}$in all of these phases, despite serial differences in individual constituents that are also of importance. The same holds true for the opposite changes in metabolic alkalosis produced by electrolyte addition $(25,26)$. In acute respiratory experiments of brief duration, such as those reported here, there is no stabilization, and recovery is marked simply by a return of the urinary acid-base output toward control levels. ${ }^{10}$ Superimposed on this return,

\footnotetext{
10 Fuller and MacLeod (15) reported that urinary ef-
} fects of respiratory acidosis were rapidly reversible, 
however, are the effects of other factors, such as diurnal fluctuations (34), the wearing off of the slight metabolic alkalosis previously induced in the subjects exposed to $\mathrm{CO}_{2}$ inhalation, persistence of slight differences in respiration, and late effects of the imposed diuresis.

Once the "balance" between the existing respiratory disturbance and the compensatory metabolic acidosis or alkalosis (produced by the kidney) has been reached, there similarly may be nothing distinctive about the urinary excretion for individual ions except as related to the accompanying composition of plasma. For example, in one of our unpublished cases of chronic $\mathrm{CO}_{2}$ retention with a plasma $\mathrm{PCO}_{2}$ of $120 \mathrm{~mm}$. $\mathrm{Hg}$, urinary chloride excretion exceeded $40 \mathrm{mEq}$. per day, corresponding approximately to the intake, despite an extremely low plasma chloride concentration of $74 \mathrm{mEq}$. per liter. It is not surprising that the observer may erroneously conclude that renal compensations are unimportant in such disturbances if he directs his attention to the urinary composition alone. Determination of clearance rates or reabsorptive rates for acid-base factors will, however, disclose the presence of renal response.

\section{Regulation of renal bicarbonate excretion}

Change in the rate of excretion of bicarbonate was the principal anionic response of the kidney to the respiratory disturbances. In a preliminary report of the present work (3) it was stated that bicarbonate excretion rate correlated better with plasma $\mathrm{pH}$ than with other plasma factors such as $\mathrm{PCO}_{2}$ or $\mathrm{HCO}_{3}{ }^{-}$concentration. About the same time Brazeau and Gilman (35), Dorman, Sullivan, and Pitts (36), and Relman, Etsten, and Schwartz (37) each reported studies showing that the reabsorption of bicarbonate was more closely related to the $\mathrm{PCO}_{2}$ of the blood than to $\mathrm{pH}$ or concentration of bicarbonate. Several recent references misconstrue our data and interpretations as in disagreement with the above groups. This confusion has resulted from the failure to note

while hyperventilation produced lasting depression of titratable acid excretion and increase in bicarbonate excretion. These findings in anesthetized dog experiments differ from the return to control values after hyperventilation noted in humans in our studies and those of Stanbury and Thomson (20). the terms in which the data are reported. Examination of the directional changes given in Figure 4 will disclose that actually no disagreement exists. In our consideration of the over-all effect of the renal compensation on the body we stressed output (excretion). The figure illustrates that $\mathrm{HCO}_{3}^{-}$ excretion is decreased in respiratory acidosis and increased in both respiratory and metabolic alkalosis. Since both plasma $\mathrm{PCO}_{2}$ and plasma $\mathrm{HCO}_{3}{ }^{-}$ concentration move in the opposite directions in respiratory alkalosis and metabolic alkalosis, it is obvious that $\mathrm{HCO}_{3}^{-}$excretion is better correlated with plasma $\mathrm{pH}$. The three groups of investigators mentioned above, however, were interested primarily in the renal component due to active tubular processes. In studying the regulation of these processes they therefore logically stressed bicarbonate reabsorption. Figure 4 shows that the rate of $\mathrm{HCO}_{3}^{-}$reabsorption is decreased in respiratory alkalosis but increased in metabolic alkalosis (electrolyte addition). Obviously, then, reabsorption does not correlate well with plasma $\mathrm{pH}$ but could be correlated (in direction of change) with either plasma bicarbonate concentration or $\mathrm{PCO}_{2} \cdot{ }^{11}$ In experiments carefully designed to test this point the groups mentioned above found in dogs that $\mathrm{PCO}_{2}$ was the more closely related. If our human data are used for calculation of correlation coefficients it is found that reabsorptive rate does correlate somewhat better with $\mathrm{PCO}_{2}$ than with plasma bicarbonate concentration. Thus, it should be apparent that conclusions about changes in bicarbonate excretion cannot be considered as simply the opposite of changes in reabsorption. If the filtered load changes sufficiently, rates of reabsorption and excretion may change simultaneously in the same direction, as happened in the bicarbonate administration experiments.

\section{Renal excretion of potassium}

The predominance of changes in potassium excretion rate over those of sodium is a striking result since the sodium greatly exceeds potassium in the glomerular filtrate. At the end of either hyperventilation or $\mathrm{CO}_{2}$ inhalation the significance of change in potassium excretion compared to con-

\footnotetext{
11 Several workers have advanced the suggestion that this effect may be mediated through changes in $\mathrm{pH}$ within the tubule cells $(38,39)$.
} 
trol rate clearly exceeded that of the corresponding changes in sodium excretion. Indeed in the hyperventilation experiments even the absolute magnitude of increased excretion was much greater $\left(\mathrm{K}^{+}+183 \mu \mathrm{Eq}\right.$. per min., $\mathrm{Na}^{+}+70 \mu \mathrm{Eq}$. per min.). Since potassium is the predominant intracellular cation one might suggest that the release of potassium from body cells as a compensatory mechanism to hyperventilation is involved. A close relation between potassium and buffering action of intracellular fluid has been prominently considered since the work of Darrow and his associates $(40,41)$ on certain potassium deficiency states. The calculated "cellular exchanges" of potassium in our experiments (1) would affect extracellular concentration in the same direction as do the changes in urinary excretion of potassium. Thus they are in the direction opposite to that which would be required to explain the urinary findings through a change in plasma potassium concentration and secondarily in renal load. The change in potassium excretion under these circumstances might result from a reciprocal relationship between the tubular secretions of hydrogen ion and potassium as suggested by Berliner, Kennedy, and Orloff (42).

\section{Sodium and chloride excretion.}

In extracellular fluid, changes in buffer base are approximately equal to changes in $\mathrm{Na}^{+}-\mathrm{Cl}^{-}$. Yet during the first half hour of respiratory acidbase disturbances those changes that did occur in sodium and chloride excretion tended to be in the same direction. Therefore urinary $\mathrm{Na}^{+}-\mathrm{Cl}^{-}$ excretion showed little variation and change in fixed ions accompanying $\Delta U V_{\mathbf{H}^{+}}$was associated predominantly with $\mathrm{K}^{+}$. The alterations in sodium and chloride excretion were not directly correlated with the continuation and withdrawal of the experimental stimuli, and were not necessarily opposite in direction in the acidosis from the alkalosis experiments. Our data therefore do not support the suggestion of Stanbury and Thomson (20) that a fall in chloride output following acute hyperventilation may represent a separate acidbase mechanism favoring conservation of "fixed acid" $\left(\mathrm{Cl}^{-}\right)$. Since these parallel changes of sodium and chloride excretion are not concerned with preserving acid-base homeostasis, some other physiological process must be involved. This might concern mechanisms of electrolyte conservation, hormonal factors, or renal hemodynamic changes. Renal plasma flow, but not glomerular filtration rate, showed a positive correlation with sodium and chloride excretion in the hyperventilation studies, while neither showed statistically significant changes with $\mathrm{CO}_{2}$ inhalation.

\section{Excretion of other ions}

Phosphate excretion changes in two ways: as the rate of total phosphate output (in $\mu \mathrm{M}$ per min.) and as the proportion as $\mathrm{HPO}_{4}=$ or as $\mathrm{H}_{2} \mathrm{PO}_{4}^{-}$. Changes in the buffer role of phosphate as a transporter of $\mathrm{H}^{+}$are included in the titratable acidity, of which phosphate is an important part. This may be expressed quantitatively by the difference between the excretion rate of phosphate in $\mu$ Eq. per min. at the observed $\mathrm{pH}$ and the calculated rate in $\mu \mathrm{Eq}$. per min. that would occur if the same number of $\mu \mathrm{M}$ were excreted at a $\mathrm{pH}$ of 7.4. An increase in $\mu \mathrm{M}$ per min. phosphate excretion is regularly observed in respiratory acidosis (17, 30 , Table $I B$ ) and a decrease in respiratory alkalosis $(17,19,20$, Table I A), but these changes are small relative to the other changes. Calculated undetermined anion excretion showed only very small changes in both types of experiments. It is therefore unlikely that changes in excretion of sulfate, lactate or organic acids are quantitatively important compared to the other changes reported.

\section{SUMMARY}

Acute respiratory alkalosis by voluntary hyperventilation for approximately thirty minutes, or acidosis by $\mathrm{CO}_{2}$ inhalation for a similar period, were induced in normal human subjects. The urinary excretion of water and electrolytes and the acid-base pattern of the urine were observed in multiple clearance periods before, during and after the respiratory stimuli.

In respiratory alkalosis the kidney responded promptly by retaining hydrogen ion compared to control excretion, measured principally as an increase in output of bicarbonate with potassium. Urinary $\mathrm{pH}$ rose and titratable acidity, ammonium ion, and phosphate excretion fell. The potassium effect appeared to be due to renal regulation rather than secondary to systemic intracellular adjust- 
ments. Chloride excretion tended to vary with that of sodium, increasing slightly during hyperventilation and then falling far below the control level.

Changes observed during respiratory acidosis were, for most variables, opposite in direction to those noted during hyperventilation. They were smaller in magnitude since the experimental acute respiratory acidosis by $\mathrm{CO}_{2}$ inhalation was a milder acid-base disturbance than hyperventilation as indicated by degree of plasma changes and estimation of total extracellular acid-base disturbance. Changes in excretion of sodium and chloride were not as definite as those in other factors and were not always opposite in direction in the two types of experiment. At least part of this change (when sodium and chloride change in the same direction) appears not immediately concerned with acid-base homeostasis. If the urine is already acid the typical urinary changes may not be evident during acute $\mathrm{CO}_{2}$ inhalation.

Renal mechanisms account for only a small part of the adjustments observed in experiments of short duration, but become more important with prolonged stimuli. The rate of renal acid-base compensation is considerably greater in acute extracellular alkalosis of similar magnitude induced by sodium bicarbonate administration. The urinary patterns described are typical of the "displacement" phase of respiratory disturbances. With chronic respiratory disturbances a stabilized situation may be reached in which changes are not evident in rates of urinary output of hydrogen ion except as compared to abnormalities of the acid-base composition of plasma; if "recovery" then occurs the direction of hydrogen ion excretion typical of the "displacement" phase is reversed.

The data are compatible with the finding of others that the tubular reabsorption of $\mathrm{HCO}_{3}{ }^{-}$is better correlated with plasma $\mathrm{PCO}_{2}$ than with other extracellular acid-base factors. Changes in excretion of $\mathrm{HCO}_{3}{ }^{-}$, however, which determine the effect on the body, correlate with plasma $\mathrm{pH}$ and not with plasma $\mathrm{PCO}_{2}$, if one considers both respiratory and metabolic disturbances.

\section{REFERENCES}

1. Elkinton, J. R., Singer, R. B., Barker, E. S., and Clark, J. K., Effects in man of acute experimental respiratory alkalosis and acidosis on ionic transfers in the total body fluids. J. Clin. Invest., 1955, 34, 1671.

2. Singer, R. B., Clark, J. K., Barker, E. S., and Elkinton, J. R., The effects of acute respiratory alkalosis on electrolyte excretion and renal hemodynamics in man. J. Clin. Invest., 1952, 31, 663.

3. Elkinton, J. R., Singer, R. B., Barker, E. S., and Clark, J. K., Effects of acute respiratory acidosis on electrolyte excretion in man. Federation Proc., 1953, 12, 38.

4. Smith, H. W., Finkelstein, N., Aliminosa, L., Crawford, B., and Graber, M., The renal clearances of substituted hippuric acid derivatives and other aromatic acids in dog and man. J. Clin. Invest., 1945, 24, 388.

5. Brod, J., and Sirota, J. H., The renal clearance of endogenous "creatinine" in man. J. Clin. Invest., 1948, 27, 645.

6. Van Slyke, D. D., and Sendroy, J., Jr., Carbon dioxide factors for the manometric blood gas apparatus. J. Biol. Chem., 1927, 73, 127.

7. Van Slyke, D. D., Weisiger, J. R., and Van Slyke, K. K., Photometric measurement of urine $\mathrm{pH}$. J. Biol. Chem., 1949, 179, 757.

8. Wallace, W. M., Holliday, M., Cushman, M., and Elkinton, J. R., The application of the internal standard flame photometer to the analysis of biologic material. J. Lab. \& Clin. Med., 1951, 37, 621.

9. Harvey, S. C., The quantitative determination of the chlorids in the urine. Arch. Int. Med., 1910, 6, 12.

10. Folin, O., and Bell, R. D., Applications of a new reagent for the separation of ammonia. I. The colorimetric determination of ammonia in urine. $\mathrm{J}$. Biol. Chem., 1917, 29, 329.

11. Lowry, O. H., and Lopez, J. A., The determination of inorganic phosphate in the presence of labile phosphate esters. J. Biol. Chem., 1946, 162, 421.

12. Sendroy, J., Jr., Seelig, S., and Van Slyke, D. D., Studies of acidosis. XXII. Application of the Henderson-Hasselbalch equation to human urine. J. Biol. Chem., 1934, 106, 463.

13. Schiess, W. A., Ayer, J. L., Lotspeich, W. D., and Pitts, R. F., The renal regulation of acid-base balance in man. II. Factors affecting the excretion of titratable acid by the normal human subject. J. Clin. Invest., 1948, 27, 57.

14. Singer, R. B., and Hastings, A. B., An improved clinical method for the estimation of disturbances of the acid-base balance of human blood. Medicine, 1948, 27, 223.

15. Fuller, G. R., and MacLeod, M. B., Excretion of titratable acid during acute respiratory disturbances of acid-base balance. Am. J. Physiol., 1956, 186, 505.

16. Hilton, J. G., Capeci, N. E., Kiss, G. T., Kruesi, O. R., Glaviano, V. V., and Wégria, R., The ef- 
fect of acute elevation of the plasma chloride concentration on the renal excretion of bicarbonate during acute respiratory acidosis. J. Clin. Invest., 1956, 35, 481.

17. Brassfield, C. R., and Behrmann, V. G., A correlation of the $\mathrm{pH}$ of arterial blood and urine as affected by changes in pulmonary ventilation. Am. J. Physiol., 1941, 132, 272.

18. McCance, R. A., and Widdowson, E. M., The response of the kidney to an alkalosis during salt deficiency. Proc. Roy. Soc., London, s.B., 1936, 120, 228.

19. Brown, E. B., Jr., Campbell, G. S., Elam, J. O., Gollan, F., Hemingway, A., and Visscher, M. B., Electrolyte changes with chronic passive hyperventilation in man. J. Applied Physiol., 1949, 1, 848.

20. Stanbury, S. W., and Thomson, A. E., The renal response to respiratory alkalosis. Clin. Sc., 1952, 11, 357.

21. McDonald, I. R., Coats, D. A., and Munro, J., The renal regulation of the extracellular ionic pattern during hyperventilation. Australian J. Exper. Biol. \& M. Sc., 1953, 31, 425.

22. Ochwadt, B., Uber Rückresorption und Ausscheidung von Bicarbonat durch die Niere während der $\mathrm{Hy}$ perventilationsalkalose. Arch. f. d. ges. Physiol., 1950, 252, 529.

23. Dill, D. B., Talbott, J. H., and Consolazio, W. V., Blood as a physico-chemical system. XII. Man at high altitudes. J. Biol. Chem., 1937, 118, 649.

24. Yeomans, A., and Stueck, G. H., Jr., Clinical-chemical studies of acid-base abnormalities. Changes in acid-base balance observed in renal and respiratory disease. Am. J. Med., 1952, 13, 183.

25. Singer, R. B., Clark, J. K., Barker, E. S., Crosley, A. P., Jr., and Elkinton, J. R., The acute effects in man of rapid intravenous infusion of hypertonic sodium bicarbonate solution. I. Changes in acidbase balance and distribution of the excess buffer base. Medicine, 1955, 34, 51.

26. Singer, R. B., Crosley, A. P., Jr., Elkinton, J. R., Barker, E. S., and Clark, J. K., The acute effects in man of rapid intravenous infusion of hypertonic sodium bicarbonate solution. III. Changes in urinary electrolyte excretion and renal hemodynamics. In preparation.

27. Schäfer, K-E., Atmung und Säure-Basengleichgewicht bei langdauerndem Aufenthalt in $3 \% \mathrm{CO}_{2}$. Arch. f. d. ges. Physiol., 1949, 251, 689.

28. Longson, D., and Mills, J. N., The failure of the kidney to respond to respiratory acidosis. J. Physiol., $1953,122,81$.
29. Barbour, A., Bull, G. M., Evans, B. M., Jones, N. C. Hughes, and Logothetopoulos, J., The effect of breathing 5 to $7 \%$ carbon dioxide on urine flow and mineral excretion. Clin. Sc., 1953, 12, 1.

30. Denton, D. A., Maxwell, M., McDonald, I. R., Munro, $J$, and Williams, W., Renal regulation of the extracellular fluid in acute respiratory acidaemia. Australian J. Exper. Biol. \& M. Sc., 1952, 30, 489.

31. Dowds, E. G., Brickner, E. W., and Selkurt, E. E., Renal response to hypercapnia. Proc. Soc. Exper. Biol. \& Med., 1953, 84, 15.

32. Sullivan, W. J., and Dorman, P. J., The renal response to chronic respiratory acidosis. J. Clin. Invest., 1955, 34, 268.

33. Sartorius, O. W., Roemmelt, J. C., and Pitts, R. F., The renal regulation of acid-base balance in man. IV. The nature of the renal compensations in ammonium chloride acidosis. J. Clin. Invest., 1949, 28, 423.

34. Stanbury, S. W., and Thomson, A. E., Diurnal variations in electrolyte excretion. Clin. Sc., 1951, 10, 267.

35. Brazeau, P., and Gilman, A., Effect of plasma $\mathrm{CO}_{2}$ tension on renal tubular reabsorption of bicarbonate. Am. J. Physiol., 1953, 175, 33.

36. Dorman, P. J., Sullivan, W. J., and Pitts, R. F., The renal response to acute respiratory acidosis. $\mathrm{J}$. Clin. Invest., 1954, 33, 82.

37. Relman, A. S., Etsten, B., and Schwartz, W. B., The regulation of renal bicarbonate reabsorption by plasma carbon dioxide tension. J. Clin. Invest., 1953, 32, 972.

38. Roberts, K. E., Randall, H. T., Sanders, H. L., and Hood, M., Effects of potassium on renal tubular reabsorption of bicarbonate. J. Clin. Invest., 1955, 34, 666.

39. Berliner, R. W., and Pitts, R. F., Discussion of Pitts, R. F., Sullivan, W. J., and Dorman, P. J., Regulation of the content of bicarbonate bound base in body fluids in Ciba Foundation Symposium on the Kidney. Boston, Little, Brown and Co., 1954, p. 145.

40. Darrow, D. C., Changes in muscle composition in alkalosis. J. Clin. Invest., 1946, 25, 324.

41. Cooke, R. E., Segar, W. E., Cheek, D. B., Coville, F. E., and Darrow, D. C., The extrarenal correction of alkalosis associated with potassium deficiency. J. Clin. Invest., 1952, 31, 798.

42. Berliner, R. W., Kennedy, T. J., Jr., and Orloff, J., Relationship between acidification of the urine and potassium metabolism. Effect of carbonic anhydrase inhibition on potassium excretion. Am. J. Med., 1951, 11, 274. 